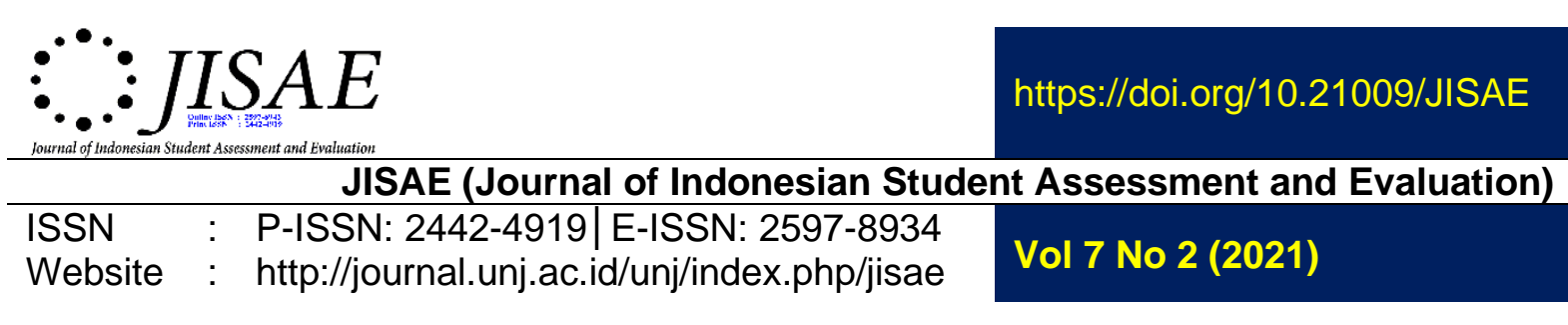

\title{
SOCIAL INEQUALITY IN TEACHERS REVIEWED BASED ON DIFFERENCES IN TEACHER EMPLOYMENT STATUS IN DKI JAKARTA
}

Irzandy Amri Maulana

University of Indonesia

\begin{abstract}
This study discusses the social gaps in teachers reviewed from differences in teacher staffing status in DKI Jakarta. The status of existing teachers is; Civil Servant Teachers (PNS), Individual Employment Contract Teachers (KKI), and School Honorer Teachers. The research aims to see how gaps occur in teachers with different staffing statuses. The study used the concept of material disparity and Dahrendorf's authority to look at gaps in teachers. Previous studies of teacher inequality have been limited to policy gaps in teachers and teacher welfare gaps. This study shows that differences in teacher staffing status can lead to material and authority gaps occurring in teachers. This study uses qualitative case studies with informants of civil servant teachers, KKI teachers, and school honorer teachers in DKI Jakarta as research subjects.
\end{abstract}

Address for Correspondence:
maulana.irzandy8@gmail.com

Keywords: Teacher, Teacher Status, Material Gap, Authority Gap

\section{INTRODUCTION}

Social inequality is a condition of inequality that exists in a society that makes a difference. This gap causes differences in achieving the resources that everyone has. Social inequalities are essential to address because gaps can lead to some things. Social inequality can lead to social distance between individuals coexisting. Rahman (2011) suggests that social distance is a separation that occurs in society, both between groups and between individuals. The social distance here is not locational or spatial but rather a social relationship between individuals and groups in society. Gaps can also result in individual differences in accessing a variety of resources. The opportunities of the rich and the poor in accessing resources will undoubtedly be different. The access that the rich have is more 1 mumpuni than the poor. Alternatively, in other words, the gap also determines different opportunities to acquire existing resources.

Social inequality initially has to do with economic or material aspects only. This is based on Marx's thoughts on conflicts that consider the gap in material ownership by the community. It is caused by exploiting the group of capital owners against the group that does not have so that there is a gap in it (Zuldin, 2019). Marx sees that the gap occurs only because of differences in the ownership of material production tools between the bourgeois and proletarian groups. Dahrendorf sees that the factors that cause social inequality are not just material. The power and authority can see the 
cause of inequality in the society of the community (Dahrendorf, 1959). The difference in power and authority that each individual has in society is considered to determine the gaps that exist and have an impact on the ownership of the material obtained (Zuldin, 2019).

Dahrendorf takes the definition of authority from Weber. Weber sees authority as a legitimate force that can be used with the consent of those controlled by it and that conflicts are created by the distribution of authority and power (Guclu, 2014). Danrendorf says that an essential difference between authority and power lies in that power is essentially related to an individual's personality. Authority is always associated with a social position or role (Dahrendorf 1959). Weber and Dahrendorf see authority as a cause of conflict and social inequality. The main point of this authority is that authority is not attached to an individual but rather a position, as Dahrendorf says. In this case, the position can be either a position, a title, or a status obtained by an individual. Dahrendorf suggests the existence of power relations that include subordinates and superiors, the existence of a dichotomy between those in power and rule (Demartoto, 2010). In this case, power and control enter the realm of power because individuals can have power. These relationships that include subordinates and superiors are related to authority, as they are attached to individuals' positions.

Social inequality also occurs for teachers. Previous studies on teacher inequality have addressed policy gaps in teachers. The study written by Fauzi \&Syafar, 2017, and Arifin \&Arifin, 2019 explained that there is a policy gap between civil servant teachers and honorer teachers. This gap has an impact on the material differences each teacher gets. Civil servant teachers have policies that govern the acquisition of materials, while Honorer Teachers do not have them. Next there is a study written by (Verdugo \&Schneider, 1994) on the gender gap in teachers that has an impact on the differences in material obtained between male teachers and female teachers, resulting in male teachers getting higher material than female teachers. Material gaps in teachers also occur between public school teachers and madrasah teachers, a study written by (Muslikh, 2019) explains that the material obtained by public school teachers is higher than that of madrasah teachers.

The conclusion of previous studies on teacher inequality is that gaps are more based on material gaps. While there are studies that found gender gaps in teachers, they also affect income differences. Thus, based on previous studies, it can be said that gaps in teachers are a phenomenon, especially material gaps.

Social inequalities that occur in teachers can occur due to differences in the staffing status of existing teachers. The status of teacher staffing in DKI Jakarta for public schools is Civil Servant Teachers (PNS) and Honorer Teachers. They are divided into Regional Honorer Teachers or Honda. However, DKI Jakarta uses the terminology Of Individual Employment Contract Teachers (KKI) and School Honorer Teachers or Pure Honorers. Based on existing data collected from Dapo Disdakmen Kemendibud 2020/2021, the number of teachers in DKI Jakarta amounted to 95,572 overall.

Civil Servant Teachers are Civil Servant Teachers whom the government has appointed after going through the selection held by the government. Civil servant teachers have obligations and rights that have been regulated in Law No. 43 of 1999 that regulates it and have guarantees from the government. The basic salary of civil servant teachers is regulated through PP No. 15 of 2019, with salaries according to their class. KKI teacher is an honorary teacher in DKI Jakarta province. The definition of KKI in Governor Regulation No. 235 of 2015 is an agreement between Non-Civil 
Servant Teachers and local governments that contains the parties' functional requirements, rights, and obligations. Honorer School Teachers are honorer teachers with employment agreements between teachers and schools only. However, no rules or policies govern School Honorer Teachers, so legally, certainty is still not guaranteed. Also, an honorarium is not clear compared to KKI Teachers and Civil Servant Teachers. The number of Honorer School Teachers in each school today is usually tiny compared to $\mathrm{KKI}$ teachers and civil servant teachers.

Social disparities that occur in teachers caused by differences in staffing status can be various things. In some contexts, from the beginning, materially, that means related to the welfare of the teacher itself. Next, because of the social status of these teachers in the community, the difference in the status of existing teachers can determine the community's view of the teacher. Certainty of career, future and additional income can also be a gap because of the difference in status. Civil servant teachers certainly have certainty until retirement and fixed income every month. In contrast, KKI Teachers each year evaluated by the Local Government and Honorer School Teachers do not have certainty about staffing status with the future. In the structure of teachers in each school, social gaps can also exist, whether teachers KKI and Honorer teachers are placed in the school's organizational structure and have authority like other civil servant teachers. Last is the opportunity. The opportunity here can be seen in several things; opportunities to get the same material, opportunities to develop in teaching, and other opportunities.

With different statuses and other legal certainties, the material obtained, and the authority possessed are different. Especially in Honorer School, Teachers who do not have legal certainty to regulate it will not have great material and high authority. This can also cause a sense of injustice for School Honorer Teachers legally because no regulations govern the wages of School Honorer Teachers (Arifin, W and Arifin, R, 2019). The existing regulations have created a social gap between Honorer School Teachers, Civil Servant Teachers, and KKI Teachers.

This study looks at the gaps that occur in DKI Jakarta teachers with differences in staffing status. This is because DKI Jakarta has the highest Provincial Minimum Wage, which indirectly affects the income earned by teachers, in this case, KKI Teachers. KKI teachers who are notable honorer teachers have a higher income than Honorer School Teachers. Whereas both are honorer teachers, it is just that KKI teachers can get better welfare than School Honorer Teachers. The difference in the fate of these two honoree teachers becomes interesting because they are both honorer teachers, but there is a gap between them. If juxtaposed with the staffing status of other teachers, namely civil servant teachers, there will be a gap between teachers and differences in staffing status.

The distribution of the number of teachers in DKI Jakarta between civil servant teachers, KKI teachers, and school honorer teachers whose number is lame is interesting to research. Currently, there are not many honorer schoolteachers in DKI Jakarta, especially high school, only 1 to 2 . The number of KKI Teachers in each school can reach 3 to 6 teachers. Civil servant teachers have a considerable amount because every time there is an opening CPNS teacher, then the position of Honorer Teacher will be eliminated just like that. If the percentage of teachers in each school is quite far, then the gap between civil servant teachers, $\mathrm{KKI}$ teachers, and honorer teachers can occur. 


\section{METHODS}

This study uses qualitative because it departs from the assumption of gaps in teachers based on differences in teacher staffing status, using the concept of social inequality. Qualitative use in this study also aims to explore the meaning of the difference in teacher staffing status, which then becomes a social gap. Qualitative research is derived from the assumptions and uses of interpretation or theoretical frameworks that form or influence the study of research problems related to meaning imposed by individuals or groups on a social or human problem (Cresswell, 2004:59). Somantri (2005) finds qualitatively trying to construct reality and understand its meaning, so qualitative research usually pays excellent attention to processes, events, and orientations. Therefore, a qualitative researcher should master a theoretical framework of the assumptions that want to be studied.

The type of research used in this study is a case study. The use of case studies in this study is due to wanting to see the possibility that occurs from social inequality events based on differences in staffing status in detail and depth, as is key to case study research. According to Hodgetts \&Stolte (2012), that allows investigating certain social events, situations, or conditions to provide insight into the process that explains how a particular event or situation occurred. Bryman (2012) suggests that case studies focus on collecting data using only one or two units of analysis in a particular case study.

The data in this study was obtained by conducting in-depth interviews of informants and also through literature studies. Informants in this study are teachers in the DKI Jakarta environment with the status of staffing civil servant teachers, KKI teachers, and honorer schoolteachers. Interviews were also conducted with related stakeholders, in this case, the Directorate General of Teachers and Education Personnel of the Ministry of Education, the professional organization of teachers, in this case, the Association of Education and Teachers (P2G), and also to educational observers. In this case, conduct not only in-depth interviews but also verify the data that has been obtained. The literature review chosen by the author is a concept of social inequality and inequality for teachers.

\section{RESULT and DISCUSSION Differences in Staffing Status Cause Teacher Gap}

Different teacher staffing status is the cause of gaps in teachers. Currently, teachers' staffing status in DKI Jakarta is civil servant teachers, KKI teachers, and honorer schoolteachers. Civil servant teachers are teachers whom the government has appointed after passing the government's selection and tests. KKI teachers are non-civil servant teachers who have contract employment agreements with the Provincial Government of DKI Jakarta. Honorer School Teacher is a teacher who has a contract work agreement with the school. Civil servant teachers and KKI teachers can be employees directly under the auspices of the Provincial Government of DKI Jakarta. At the same time, The Honorer School Teacher is an employee under the auspices of the principal.

The gap occurs because of teacher status and policy differences (Arifin \&Arifin, 2019). The point is that existing policies are a gap in teachers themselves. Suppose the policy on basic salaries of civil servant teachers stipulated in PP No. 15 of 2019 or KKI Teachers based on Pergub DKI Jakarta No. 235 of 2015. The two policies regulate the amount of basic salary owned by civil servant teachers and KKI teachers, while school honorer teachers do not have policies that govern them. So, the basic salary owned by the School Honorer Teacher is erratic based only on the teacher's 
agreement with the principal followed by the school's ability. The existing policy already shows a gap in teachers, which also causes injustice to School Honorer Teachers.

They review the policy governing the amount of basic salary received by civil servant teachers and KKI teachers. Based on PP No. 15 of 2019, the basic salary of civil servants is regulated based on the rank and class because teachers at least S1 then the lowest class $3 A$ only get a basic salary of Rp. 2,579,000 to Rp. 4,236,000. This does not include the Regional Performance Allowance (TKD) owned by every Civil Servant Teacher of DKI Jakarta, which has its policy stipulated in Pergub DKI Jakarta No. 13 of 2018. TKD is adjusted to the group owned. For groups, 3A to 3B receive TKD of Rp. 5,480,000. The basic salary of KKI Teachers stipulated in Pergub DKI Jakarta No. 235 of 2015 under the Regional Minimum Wage (UMR) of DKI Jakarta, then approximately $\mathrm{Rp} .4,236,400$. There is no regulation on basic salary for School Honorer Teachers, so the salaries received by Honorer School Teachers vary in each school, the range is from Rp. 2.000.000 to Rp.4.000.000 depending on each school's ability and the teacher data is already in Dapodik or not.

Civil servant teachers and $\mathrm{KKI}$ teachers have policies that regulate basic salaries and are supported by enough basic salary compared to School Honorer Teachers who do not have policies that govern their basic salaries. Because it does not have a policy that regulates the basic salary of Honorer School Teachers, the honor received by Honorer School Teachers from each school is different. This is coupled with the basic salary that is far below civil servant teachers and KKI teachers. From the explanation above, it appears that the School Honorer Teacher does not have regulations on salaries, coupled with inadequate salary acquisition. These two things are very closely related. If rules govern the basic salary of Honorer Teachers of Schools, then the basic salary of Honorer School Teachers will be more appropriate than currently accepted. Alternatively, at least have clarity in the legal aspects regarding the basic salary of Honorer Teachers School.

\section{Material Gap in Teachers in DKI Jakarta}

The material in this study is nominal, but how the material is used for teachers. The teacher material gap sees a difference in the teacher's ability to use the materials they have in terms of household needs and teaching and learning needs. In this case, the occurrence of material gaps in teachers is based on differences in teacher staffing status that result in material differences in teachers. Thus making each teacher has different material skills to meet household needs or teaching and learning needs.

Although the material gap sees the nominal difference in the material, the material itself is pretty decisive. This can be seen from the needs of each teacher to be able to improve competency skills and support the learning process. Civil servant teachers can easily follow the existing training, both paid and facilitated by the government, for civil servant teachers to improve their existing competencies. If paid, civil servant teachers can use the funds owned to improve the competence of teachers. Unlike KKI Teachers, what else with Honorer School Teachers if they want to improve teacher competence by attending training and seminar. $\mathrm{KKI}$ teachers and school honorer teachers must use their own money from their basic salaries. KKI teachers may still set aside basic salaries under the DKI Jakarta UMR. It is tricky for Honorer School Teachers to improve their competence by attending training or seminars paid for with low salaries.

Based on the facts in the field, civil servants can use TKD for the needs of the learning process or improve its comprehension. Kin TKD is performance. Improving competence is like improving the performance of civil servant teachers. Indirectly, civil 
servant teachers should be responsible for kindergarten by improving their performance, improving competence, or buying the needs of the learning process. This is not the case with KKI Teachers or School Honorer Teachers, as both do not get performance allowances. Therefore, many KKI Teachers and School Honorer Teachers still do not set aside their materials to improve competence or buy their materials or learning materials.

Household needs are still the primary choice of every teacher in allocating their materials. If $80 \%$ of teachers in Indonesia never allocate a portion of their salary to buy books to support their profession (Darmaningtyas, 2015:127). There are several fundamental reasons why teachers do not allocate their salaries for this. Of course, the first is due to low salaries, and the second prioritizes the needs of daily life. If the teacher is still thinking about the stomach or household needs, then indirectly, the teachers have not prospered. Referring to Salihu (2018), one of the prosperous teachers is not thinking about household needs anymore.

Darmaningtyas (2015) suggests that many teachers still use their salaries for stomach needs rather than improving the teacher's abilities. This is also appreciated by Honorer School Teachers, who prefer to use existing materials for their immediate living needs rather than improving their competence by attending seminars and training. Not only that, to improve competence, buy teaching materials or even new books and laptops, The Honorer School Teacher will think twice. Because the material owned by The Honorer Teacher of the School is not extensive, it must be competent to organize the material and must prioritize household needs is a wise choice. What needs to be underlined is that The Honorer School Teacher does not want to improve their competence or buy learning tools or materials. However, the rough material condition makes them not choose to use the material they have for it.

Civil servant teachers with their materials are more able and easy to improve competence because it is supported by kindergarten. Civil servant teachers can also buy tools or materials for the needs of the learning process independently, using the materials they have. In contrast to KKI Teachers, who prioritize household needs first, improve competence, or buy tools or materials for the learning process. However, not a priority does not mean using materials to improve competence or to use tools or materials of the learning process. There are KKI teachers who use the material to improve competence or buy learning tools or materials. For Honorer School Teachers who have low salaries, of course, they must be more competent in allocating their materials. Therefore, Honorer School Teachers prefer to use their materials for daily needs or household needs rather than improve competence or buy tools or materials of the learning process.

Differences in teacher staffing status do not necessarily make the teaching burden or teacher workload different as well. Teacher workloads are all the same regardless of differences in staffing status. Nevertheless, the material obtained by each teacher is not the same, although the burden of teaching to teachers is the same. Teachers are required to teach a minimum of 24 hours of subjects. If not fulfilled, they can fill with additional teacher duties such as becoming a HomeRoom Teacher, Student or Extracurricular Coach, Head of Labor Library, and Vice-Principal or Staff Vice-Principal. Nevertheless, unfortunately not all teacher staffing status can occupy these additional tasks.

Seeing the difference in the material in the teacher and the use of the material by the teacher indirectly causes gaps in the teacher. The material gap in teachers can widen into gaps in teacher ability because Honorer Teachers rarely use their materials to update knowledge or increase their abilities by purchasing the latest teaching 
materials or books. KKI teachers still have time to buy the latest teaching materials or books to update knowledge and increase their teaching skills. Nevertheless, civil servant teachers with their materials are better able to buy the latest teaching materials and books, so that their knowledge and abilities are growing. This also shows that the material gap in teachers has implications on the pedagogy skills of teachers because the existing material can increase the knowledge and abilities of teachers.

\section{Gap in Authority on Teachers in DKI Jakarta}

The current staffing status of teachers can be said to be an authority when referring to the concept of Dahrendorf. This means that the status obtained by each teacher is a position obtained by the individual, which in Dahrendorf's thermology of authority relates to the position. The status of civil servant teachers is considered to have a high enough authority compared to KKI Teachers and School Honorer Teachers. In school life, civil servant teachers are more respected, especially if they place a structural position in the school, giving them the high authority or being the highest caste. It is like the concept of authority that Dahrendorf (1959) presented, that authority is related to its position. In this study, the authors looked at civil servant teachers' status as a position in itself and will be higher if occupying a certain position. This also happens to the authority possessed by teachers to occupy additional tasks.

Additional teacher duties are the duties of teachers outside teaching or educating what if still have a lack of teaching hours. For example, the position of Principal and Deputy Principal can be ensured that civil servant teachers can only occupy it. Civil servant teachers and KKI teachers can occupy class Guardians, Student Council Trustees, and Staff of Vice Principals; Honorer School Teachers do not have the authority to occupy the position. Honorer School Teachers can only be extracurricular coaches. In this case, civil servant teachers have higher authority than other teachers so that they have a better chance, such as occupying certain positions accompanied by the addition of materials.

In Dahrendorf's authority gap, there is a relationship between a supervised group or individual or superior with a group or individual who becomes an employee or subordinate. Demartoto (2010) said that there is a relationship of power and subordinates between those in power and control. In the teachers also happened, there are leaders in the school, the Principal and Vice-Principal, and their ranks with ordinary teachers, especially KKI Teachers and Honorer Teachers of The School. As explained above, civil servant teachers have more authority to be principals or viceprincipals and their ranks than KKI teachers and honorer teachers. Thus, the relationship between civil servant teachers and KKI teachers and school honorer teachers is more like superiors and subordinates.

The authority of civil servant teachers is so high compared to KKI Teachers and School Honorer Teachers. It is as if the relationship that occurred civil servant teachers such as the superiors of KKI teachers and honorer teachers of the school. This happens to teachers of subjects or fields of study. Civil servant teachers with all the conditions that existed so far ordered KKI Teachers and School Honorer Teachers to make a syllabus, plan the implementation of learning, include student grades, to make questions for exam needs. Although not all, this happened and was experienced by some KKI Teachers and Honorer Teachers of Schools. KKI Teachers and School Honorer Teachers who are young, and literate of technology have indirectly been utilized by civil servant teachers who have higher authority than KKI Teachers and School Honorer Teachers.

Differences in authority in teachers also have an impact on the different treatment of each teacher. For example, if a School Honorer Teacher makes a mistake, he will 
get a threat of dismissal because the position of Honorer Teacher is not legally strong. In contrast to civil servant teachers who make a mistake only get reprimands and administrative sanctions, this is due to the position of civil servant teachers who have legitimacy. Here further strengthens that civil servants themselves are already an authority. Because authority is a position owned or obtained by a particular individual (Zuldin, 2019). So civil servants are a position in itself so that it can be said a high authority, especially can already give orders or directions.

\section{CONCLUSION}

The gap that occurs in teachers can be seen from the difference in staffing status that exists. The status of teacher staffing can determine the material owned by each teacher. The material obtained by each teacher is adjusted to the staffing status of the teacher, even for civil servant teachers determined by rank and class. Staffing status can also determine the authority owned by each teacher, as well as the rights and obligations of teachers. The opportunities obtained by each teacher are also different, again determined by the staffing status of the teacher. Thus, the social gap in teachers occurs because of differences in teacher staffing status that can determine everything.

The gap that occurs in teachers in DKI Jakarta is in accordance with Dahrendorf's thinking. That authority can cause a gap in an individual because authority can indirectly determine the material that everyone has. In the study of teachers, staffing status becomes an authority because the status of teacher staffing is a position obtained by each teacher. From the authority obtained by the teacher, in this case, the staffing status of the teacher can then determine the material owned by each teacher. Therefore, indirectly the social disparities that occur in teachers are caused by differences in authority that then determine material differences in teachers.

Therefore, several steps need to be taken by the policyholders, in this case, the central government, both the Ministry of Education and Culture as the institution responsible for education and the National Staffing Agency and the Ministry of Empowerment of State Aperture responsible for personnel administration. There needs to be the collaboration of the three sheets with the local government to determine the status of teacher staffing, especially for teachers in public schools. Civil servant teachers, KKI teachers, and school honorer teachers look the same when viewed as teaching burdens as teachers. However, there are differences in the material obtained, the authority it has, and the responsibilities it assumes. To reduce the gap in teachers, it would be good for the government to reconsider the career path of teachers in public schools. The career path in question is that The Honorer Teacher of the School can be appointed as a KKI Teacher without complicated administration, with certain conditions such as a minimum of teaching for several years. Then for $\mathrm{KKI}$ Teachers are given the opportunity to become civil servant teachers when there is a vacancy of civil servant teachers in the school, meaning appointed if it meets the competency. Then the government can divide the two staffing statuses of teachers for public schools, namely civil servant teachers and KKI teachers only. Honorer School Teachers must be abolished, in addition to the absence of regulations governing them and the low salary received.

\section{Acknowledge}

Thanks to Dr. Indera Ratna Irawaty Pattinasary, M.A or commonly called Mba Ira, for helping the author in compiling this article. The author gets tremendous help from Mba Ira in the process of writing this article. Not infrequently, Mba Ira gives notes and corrections in this article. The author also received excellent guidance from Mba Ira, so that able to compose and complete this article. 


\section{REFERENCES}

Arifin, W., \& Arifin, R. (2019). Asas Keadilan Upah Guru Honorer Dalam Perspektif Hukum (Principle of Justice for Honorary Teacher Wages in a Legal Perspective). Riau Law Journal, 3(1), 85-104.

Bryman, A. (2012). Social Research Methods: Fourth Edition. New York. USA: Oxford University Press

Creswell, John. (2014). Penelitian Kualitatif \& Desain Riset. Penj: Ahmad Lintang Lazuardi. Yogyakarta: Pustaka Pelajar

Dahrendorf, R. (1959). Class And Class Conflict In Industrial Society (Vol. 15). Stanford, CA: Stanford University Press.

Darmaningtyas. (2015). Pendidikan Yang Memiskinkan. Malang: Intrans Publishing

Demartoto, A. (2010). Strukturalisme Konflik: Pemahaman Akan Konflik Pada Masyarakat Industri Menurut Lewis Coser dan Ralf Dahrendorf. dalam Jurnal Dilema Sosiologi Issn, 0215-9635.

Fauzi, H., \& Syafar, D. (2017). Studi Tentang Kebijakan Guru Honorer Sekolah Dasar di Yogyakarta. Tadbir: Jurnal Manajemen Pendidikan Islam, 5(2), 162-172.

GÜÇLÜ, İ. (2014). Karl Marx and Ralf Dahrendorf: A Comparative Perspective On Class Formation and Conflict. Eskişehir Osmangazi Üniversitesi Iktisadi ve Idari Bilimler Dergisi, 9(2), 151-168.

Hodgetts, D. J., \& Stolte, O. E. E. (2012). Case-based Research in Community and Social Psychology: Introduction to the special issue. Journal of Community \& Applied Social Psychology, 22(5), 379-389.

H Nurochim, M. M. (2019). Implementasi Kebijakan Guru Honorer; Studi Kasus di Madrasah Kota Tangerang Selatan. Tesis. Program Studi Magister Manajemen Pendidikan Islam. Fakultas IImu Tarbiyah dan Keguruan. Universitas Islam Negeri Syarif Hidayatullah

Rahman, M. T. (2011). Glosari Teori Sosial. Bandung: Ibnu Sina Press

Somantri, G. R. (2005). Memahami metode kualitatif. Makara, Sosial Humaniora, 9(2), 57-65.

Verdugo, R. R., \& Schneider, J. M. (1994). Gender Inequality in Female-Dominated Occupation: The Earnings Of Male and Female Teachers. Economics of Education Review, 13(3), 251-264.

Zuldin, M. (2019). Ketimpangan Sebagai Penyebab Konflik: Kajian atas Teori Sosial Kontemporer. TEMALI: Jurnal Pembangunan Sosial, 2(1), 157-183. 